\title{
Ethanol stimulates the secretion of matrix metalloproteinases 2 and 9 in MCF-7 human breast cancer cells
}

\author{
NICOLAS ETIQUE, ISABELLE GRILLIER-VUISSOZ and STEPHANE FLAMENT \\ EA 3442 Aspects Cellulaires et Moléculaires de la Reproduction et du Dévelopement, \\ Université Henri Poincaré - Nancy I, Faculté des Sciences, BP 239, 54506 Vandoeuvre-lès-Nancy Cedex, France
}

Received August 1,2005; Accepted September 19, 2005

\begin{abstract}
Alcohol consumption is a well-established risk factor for hormone-dependent breast cancer. In vitro studies performed to understand the mechanisms by which ethanol acts on breast cancer cells have shown that this compound stimulates both proliferation and migration. In the present study, we show by gelatin zymography that, when exposed to ethanol, MCF-7 human breast cancer cells display a higher amount of active metalloproteinases (MMP) 2 and 9 in their culture medium. This increase is somewhat higher than those observed in the case of $17 ß$-estradiol $\left(\mathrm{E}_{2}\right)$ exposure. As expected, anti-estrogen ICI 182,780 inhibits the $\mathrm{E}_{2}$-induced overexpression of a well-known estrogen responsive gene, the progesterone receptor, in MCF-7 cells. ICI 182,780 also inhibits the $\mathrm{E}_{2}$-induced increase in MMP-2 and -9 secretion. Nevertheless, in the case of ethanol exposure, this ER antagonist was only efficient on MMP-9 secretion. In addition, although MMP-9 transcription was not sensitive to $E_{2}$ or ethanol, MMP-2 transcription was stimulated in MCF-7 cells exposed to ethanol. Collectively, these results give new insights into the effects of alcohol on breast cancer cell migration, which are not due solely to an estrogen-like activity of alcohol.
\end{abstract}

\section{Introduction}

Breast cancer is the most common cancer in women: it affects 1 in 12 women in the world and, in 2004, approximately 753,000 women were dying in Europe from this disease (1). Seventy percent of human breast cancers are related to sex hormone exposure and about $60 \%$ of all patients have hormone-dependent breast cancer which means that their tumors express estrogen receptors (ER) and require estrogens

Correspondence to: Professor Stephane Flament, Université Henri Poincaré-Nancy I, Faculté des Sciences, EA3442, Entrée 1B - 9ème étage, Boulevard des Aiguillettes, BP 239, 54506 Vandoeuvre-lèsNancy Cedex, France

E-mail: stephane.flament@persmail.uhp-nancy.fr

Key words: breast cancer, ethanol, metalloproteinases, estrogen receptor for growth (2-4). Most of the effects of these hormones on tumor development are mediated by their nuclear receptor, $\mathrm{ER} \alpha$, which induces a cascade of events leading to the transcription of estrogen responsive genes. In post-menopausal women, the concentration of estrogens in breast tumor tissue is several-fold greater than those measured in plasma (5). This is related to the fact that the expression of aromatase (CYP 19), the cytochrome $\mathrm{P}_{450}$ responsible for estrogen synthesis, is increased in breast tumors (6).

Epidemiological studies have shown that chronic abuse of alcohol not only increases significantly the incidence of breast cancer but also is associated with advanced and invasive breast tumors, suggesting that alcohol may enhance tumor development and metastatic spread $(7,8)$. These data are supported by experimental studies using animal models and cell culture systems, which show that ethanol promotes mammary tumorigenesis and stimulates proliferation as well as invasion of breast cancer cells (9-14).

Invasion and metastasis are the major causes of morbidity and mortality in breast cancer patients. They require the degradation of the extracellular matrix (ECM) and particularly the basement membrane, which acts as a barrier to tumor cell passage. This complex matrix consists of a type IV collagen, laminin, heparan sulfate proteoglycan, nidogen and fibronectin (15). The degradation of the extracellular matrix by neoplastic cells involves a cascade of proteolytic enzymes (16). Secretion of metalloproteinases, serine proteases and cathepsins appears to mediate this process. Among the members of the matrix metalloproteinase (MMP) family, gelatinase A (72 kDa gelatinase, type IV collagenase, MMP-2) and B (92 kDa gelatinase, type IV collagenase, MMP-9) play a critical role in extracellular matrix degradation and tumor cell invasion in breast cancer $(15,17)$.

A few studies show that estrogens play a key role in metastatic process since $17 ß$-estradiol stimulates the secretion of the type IV collagenases (MMP-2 and MMP-9) in breast cancer cells $(18,19)$. Moreover, expression of MMP-9 in MCF-7 cells is inhibited by anti-estrogens $(19,20)$. Recently, we have shown in ER-positive breast cancer cells MCF-7, that ethanol enhanced cell proliferation and clonal growth (14). This result is associated with an increase in ER $\alpha$ and aromatase, suggesting that the estrogen signaling pathway is stimulated by ethanol $(14,21)$. Hence, we postulated that alcohol exposure could increase the expression/activity of MMP-2 and -9 and promote metastasis. 
The results of the present work show that MMP-2 and -9 secretion is increased in ethanol-treated MCF-7 breast cancer cells, but this effect cannot be ascribed to a strict estrogenlike action of ethanol.

\section{Materials and methods}

Materials. Dulbecco's modified Eagle's medium (DMEM), L-glutamine and $17 ß$-estradiol $\left(\mathrm{E}_{2}\right)$ were purchased from Sigma-Aldrich (Saint Quentin Fallavier, France) and FCS from Eurobio (Les Ulis, France). ICI 182,780 was purchased from Tocris Cookson (Bristol, UK).

Cell culture and treatment. The MCF-7 (HTB 22; human breast adenocarcinoma, ER-positive) cell line was obtained from American Tissue Culture Collection (Rockville, MD). Cells were routinely grown at $37^{\circ} \mathrm{C}$ in a $5 \%(\mathrm{v} / \mathrm{v}) \mathrm{CO}_{2}$ humidified atmosphere. They were cultured in DMEM supplemented with $10 \%$ FCS and $2 \mathrm{mM}$ L-glutamine.

For RT-PCR analyses, cells were seeded in 6-well plates at a density of $8 \times 10^{4}$ cells/well in $2 \mathrm{ml}$ of DMEM supplemented with $5 \%$ FCS and $2 \mathrm{mM} \mathrm{L}$-glutamine. After $24 \mathrm{~h}$ of incubation to allow for cell attachment, the medium was replaced with phenol-red free DMEM supplemented with $1 \%$ FCS and $2 \mathrm{mM}$ L-glutamine. After $24 \mathrm{~h}$, the medium was replaced with fresh medium supplemented with ethanol at different concentrations $(0.0,0.1,0.3,0.5$ or $0.7 \%)$ and/or various compounds.

For gelatin zymography analyses, cells were seeded in 6-well plates at a density of $8 \times 10^{4}$ cells/well in $2 \mathrm{ml}$ of DMEM supplemented with 5\% FCS and $2 \mathrm{mM}$ L-glutamine. After 3 days of culture, this medium was removed, the cells were washed with PBS and incubated with $1 \mathrm{ml}$ of phenol-red free DMEM without FCS but with $2 \mathrm{mM}$ L-glutamine and different concentrations of ethanol $(0,0.1,0.3,0.5$ or $0.7 \%)$ and/or various compounds.

Semi-quantitative RT-PCR. Total RNA was extracted from cells using TRIzol reagent (Invitrogen, Basel, Switzerland) according to the manufacturer's instructions. cDNA was synthetized in a $20 \mu \mathrm{l}$ volume containing $2 \mu \mathrm{g}$ RNA, $1.5 \mu \mathrm{g}$ random hexamer primer, $1 \mathrm{X}$ Invitrogen buffer, $7.5 \mathrm{mM}$ DTT, $0.6 \mathrm{mM}$ of each dNTP, $4 \mathrm{U}$ RNase inhibitor, and $100 \mathrm{U}$ of MMLV reverse transcriptase (Invitrogen, Cergy Pontoise, France). The mixture was incubated for $120 \mathrm{~min}$ at $37^{\circ} \mathrm{C}$ and subsequently for $5 \mathrm{~min}$ at $94^{\circ} \mathrm{C}$ in order to stop the reaction.

The cDNAs were further amplified by PCR. The specific primers were 5'-TGCTCAAGGAGGGCCTGCCGCAGGT-3' and 5'-CTACTGAAAGAAGTTGCCTCTCGCC-3' for progesterone receptor (22) 5'-GTGCTGAAGGACACACTAA AGAAGA-3' and 5'-TTGCCATCCTTCTCAAAGTTGTA GG-3' for MMP-2 (23), 5'-CACTGTCCACCCCTCAGAGC-3' and 5'-GCCACTTGTCGGCGATAAGG-3' for MMP-9 (23) and 5'-TACATGGGTGGGGTGTTGAA-3' and 5'-AAGAG AGGCATCCTCACCCT-3' for B-actin (14). PCR was carried out in a thermal cycler in a final volume of $25 \mu$ l containing $2 \mu \mathrm{cDNA}, 1 \mathrm{X}$ Eppendorf Taq buffer, 0.5X Eppendorf Taq Master, 1.5-2.5 mM MgCl $2,125 \mu \mathrm{M}$ of each dNTP, $0.33 \mu \mathrm{M}$ of each primer, and $0.5 \mathrm{U}$ Taq polymerase (Eppendorf, Le Pecq, France). Negative controls were always included.
Amplification was carried out under the following conditions: $94^{\circ} \mathrm{C}$ for $5 \mathrm{~min}, 25-401$-min cycles at $94^{\circ} \mathrm{C}, 1 \mathrm{~min}$ at $54-65^{\circ} \mathrm{C}$, and $1 \mathrm{~min}$ at $68^{\circ} \mathrm{C}$, followed by a 10 -min extension step at $68^{\circ} \mathrm{C}$. The PCR products $(25 \mu 1)$ were mixed with loading buffer $(3 \mu 1)$ and submitted to electrophoresis in a $2 \%$ agarose gel at $90 \mathrm{~V}$ for $60 \mathrm{~min}$ at room temperature. The gel was stained with ethidium bromide, viewed and photographed on a UV-transilluminator (GelDoc 2000, Bio-Rad Laboratories). A software package (Quantity One v.4.3.1, Bio-Rad Laboratories) was used to quantify the PCR products.

Gelatin zymography. The media were collected and centrifuged at $1,500 \mathrm{x} \mathrm{g}$ for $10 \mathrm{~min}$. Supernatant proteins were precipited for $2 \mathrm{~h}$ at $4^{\circ} \mathrm{C}$ with a $70 \%$ ammonium sulphate solution. They were centrifuged at $12,000 \mathrm{x}$ g for $10 \mathrm{~min}$ and solubilized in $40 \mu 1$ of phenol-red free DMEM. Each sample was mixed with $15 \mu 1$ of a loading buffer (Tris-Base) containing 30\% glycerol, $7.7 \%$ sodium dodecyl sulphate (SDS) and $0.3 \%$ bromophenol blue at $\mathrm{pH}$ 6.8. Samples were loaded in a $10 \%$ polyacrylamide-SDS gel containing $0.1 \%$ gelatin and were electrophoresed in a mini Protean II Dual slab cell (Bio-Rad) at $100 \mathrm{~V}$ for $2 \mathrm{~h}$. Following electrophoresis, gels were washed twice for 90 min with $2.5 \%$ Triton $\mathrm{X}$-100 in Tris-buffered saline $(50 \mathrm{mM}$ Tris- $\mathrm{HCl}, \mathrm{pH} 7.4,150 \mathrm{mM} \mathrm{NaCl})$ to remove SDS. Gels were then incubated for $36 \mathrm{~h}$ at $37^{\circ} \mathrm{C}$ in catalytic buffer (50 mM Tris- $\mathrm{HCl}$, pH 7.6, $10 \mathrm{mM} \mathrm{CaCl}_{2}$ ) and stained in $0.025 \%$ Coomassie blue in methanol:acetic acid:water (10:1:10 v:v:v) for $2 \mathrm{~h}$. Finally, gels were destained with methanol:acetic acid:water (2:1:10 v:v:v) for $24 \mathrm{~h}$. Proteolytic activity appeared as clear bands on a dark blue background. The bands were identified by their molecular weight: 72 and $92 \mathrm{kDa}$ corresponding to MMP-2 and -9 , respectively. Proteolytic activity was evaluated using a GelDoc 2000 imaging system (Bio-Rad Laboratories) and a software package (Quantity One v.4.3.1).

Statistical analysis. The results are expressed as mean \pm standard error of several experiments as indicated in the text. Differences among treatment groups were tested using analysis of variance (ANOVA). Differences in which the P-value was $<0.05$ were statistically significant. In cases where significant differences were detected, specific post-hoc comparisons between treatment groups were examined using Fisher's least-significant differences test (SPSS v11.0 computer software).

\section{Results}

Ethanol and $E_{2}$ increase MMP-2 and -9 secretion in MCF-7. We evaluated the effect of ethanol and $E_{2}$ on the levels of MMP-2 and -9 of MCF-7 human breast cancer cells. Different concentrations of ethanol $(0.1,0.3,0.5$ and $0.7 \%)$ and $\mathrm{E}_{2}(1 \mathrm{nM})$ were tested. Cells were incubated with ethanol or $\mathrm{E}_{2}$ for $24 \mathrm{~h}$ and the culture medium was analyzed by gelatin zymography. At concentrations of 0.3 and $0.5 \%$, ethanol significantly increased the amounts of MMP-9 and -2 (Fig. 1). MMP-9 maximal secretion was observed for ethanol $0.3 \%$ with a 1.6-fold increase compared to control $(\mathrm{P}<0.05)$ and MMP-2 maximal secretion was observed for ethanol $0.5 \%$ with a 1.9-fold increase compared to control $(\mathrm{P}<0.05)$. Like ethanol, 


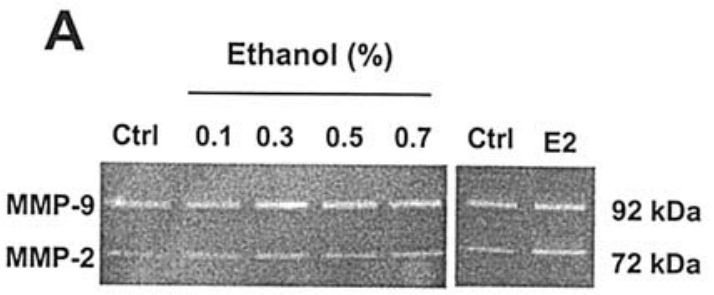

B

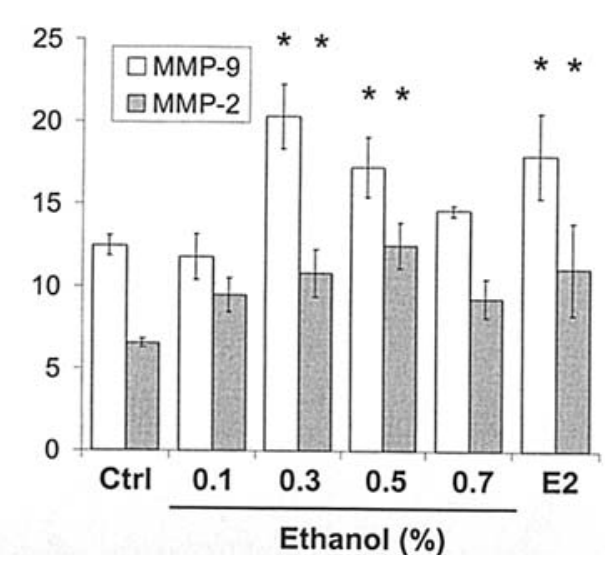

Figure 1. Ethanol and $\mathrm{E}_{2}$ stimulate MMP-2 and -9 secretion in MCF-7 human breast cancer cells. A representative zymographic gel (A) shows that MMP-2 and -9 secretion is increased when MCF-7 cells are treated for $24 \mathrm{~h}$ with various concentrations of ethanol (0.1-0.7\%) or $\mathrm{E}_{2}(1 \mathrm{nM})$. Clear bands represent collagenases MMP-2 and -9 and were quantified by densitometry. Analysis of 5 independent experiments is represented on the histogram (B). Error bars represent standard deviations. *Significantly different from untreated control $(\mathrm{P}<0.05)$.

$\mathrm{E}_{2}$ significantly stimulates the secretion of MMP-2 and -9 by MCF-7 breast cancer cells (1.8- and 1.4-fold respectively).

Involvement of the estrogen signaling pathway. Previous studies have shown that ethanol stimulates the estrogen signaling pathway in $\mathrm{MCF}-7$ human breast cancer cells $(14,21)$. Hence, we postulated that the effect of ethanol on the MMP level was dependent on the estrogen signaling pathway. To test this hypothesis, we used an anti-estrogen; the 'pure' antagonist, ICI 182,780 (24).

First, we determined the concentration of ICI 182,780 able to block the estrogen signaling pathway in MCF-7 cells. We analyzed, by semi-quantitative RT-PCR, the expression of a well-known estrogen responsive gene, the progesterone receptor (PR) (25). MCF-7 cells were treated by $E_{2}(1 \mathrm{nM})$ in the presence of different concentrations of ICI $182,780(1,10$ and $100 \mathrm{nM})$. We observed a dose-dependent inhibition of $\mathrm{E}_{2}$-induced $\mathrm{PR}$ overexpression with maximum efficiency at the concentration of $100 \mathrm{nM}$ ICI 182,780 (Fig. 2A).

Then, we determined if this optimal concentration of ICI 182,780 could inhibit $\mathrm{E}_{2}$ - and ethanol-induced increase in MMP secretion. Results showed that ICI 182,780 inhibits significantly the increase in MMP-9 (Fig. 2B) and -2 (Fig. 2C) secretions that is observed when $\mathrm{MCF}-7$ cells are stimulated by $\mathrm{E}_{2}(1 \mathrm{nM})$. ICI 182,780 has the same effect on MMP-9 secretion induced by ethanol $(0.3 \%$ or $0.5 \%)$ (Fig. $2 \mathrm{~B})$. In
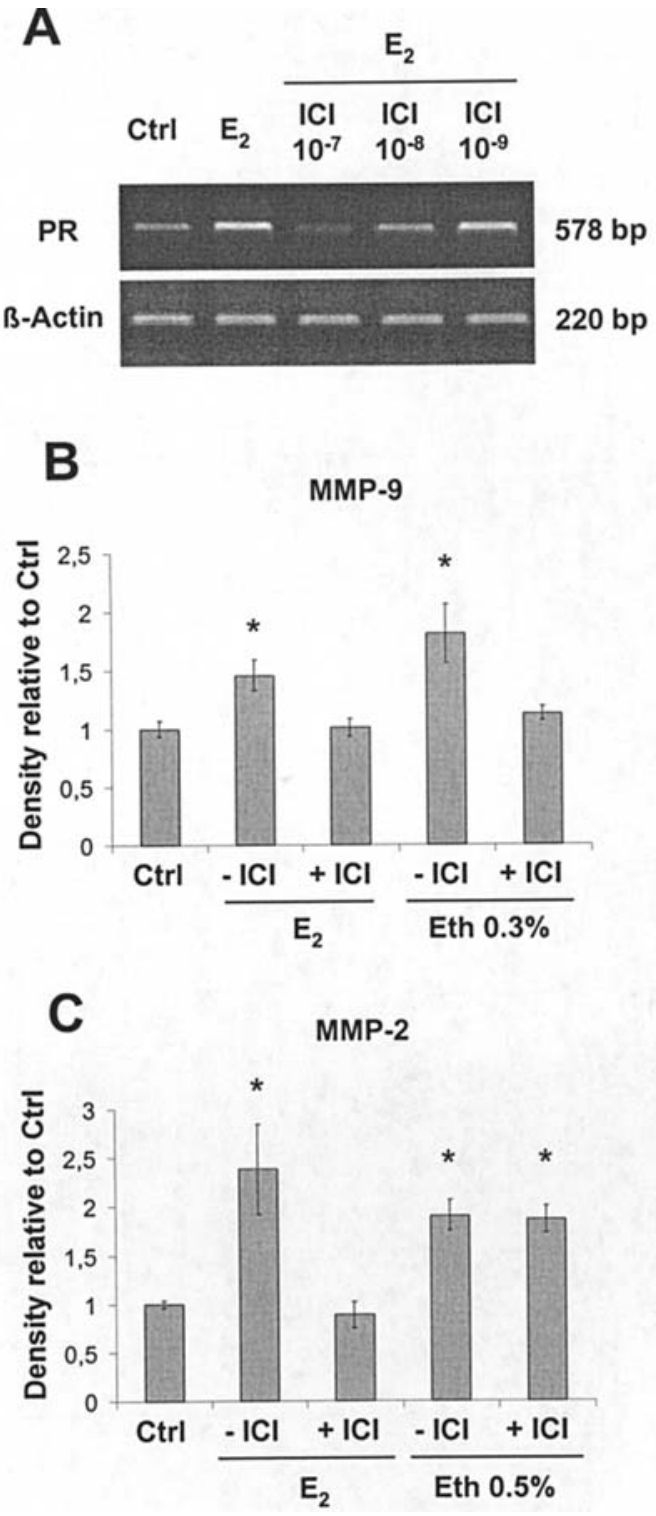

Figure 2. The 'pure' anti-estrogen, ICI 182,780, inhibits ethanol-induced increase in MMP-9 secretion whereas MMP-2 secretion still increases. (A) Representative gel of a RT-PCR analysis showing that $10^{-7} \mathrm{M}$ ICI inhibits PR overexpression that is usually observed after 24-h 17B-estradiol treatment $(1 \mathrm{nM})$ of MCF-7 cells. When used at the same concentration, ICI 182,780 affects the $\mathrm{E}_{2}$-induced increase in MMP secretion and ethanol-induced increase in MMP-9 secretion. Results of the semi-quantitative analysis performed on 3 independent experiments are shown for MMP-9 (B) and -2 (C). "Significantly different from untreated control $(\mathrm{P}<0.05)$.

contrast, ICI 182,780 did not affect the ethanol-induced increase in MMP-2 secretion (Fig. 2C).

Ethanol stimulates MMP-2 transcription in MCF-7 cells. Finally, in order to better characterize the effect of ethanol on MMP-2 and -9 in MCF-7 cells, we analysed their mRNAs. The results of our RT-PCR studies showed that $\mathrm{E}_{2}(1 \mathrm{nM})$ does not affect the transcription of these MMPs (Fig. 3). So, $\mathrm{E}_{2}$ stimulates MMP-2 and MMP-9 secretion without increasing their transcription. For ethanol treatment, we observed no effect on MMP-9 transcription but a high increase in the MMP-2 mRNA level, demonstrating that MMP-2 expression is not affected identically by ethanol and $\mathrm{E}_{2}$. 

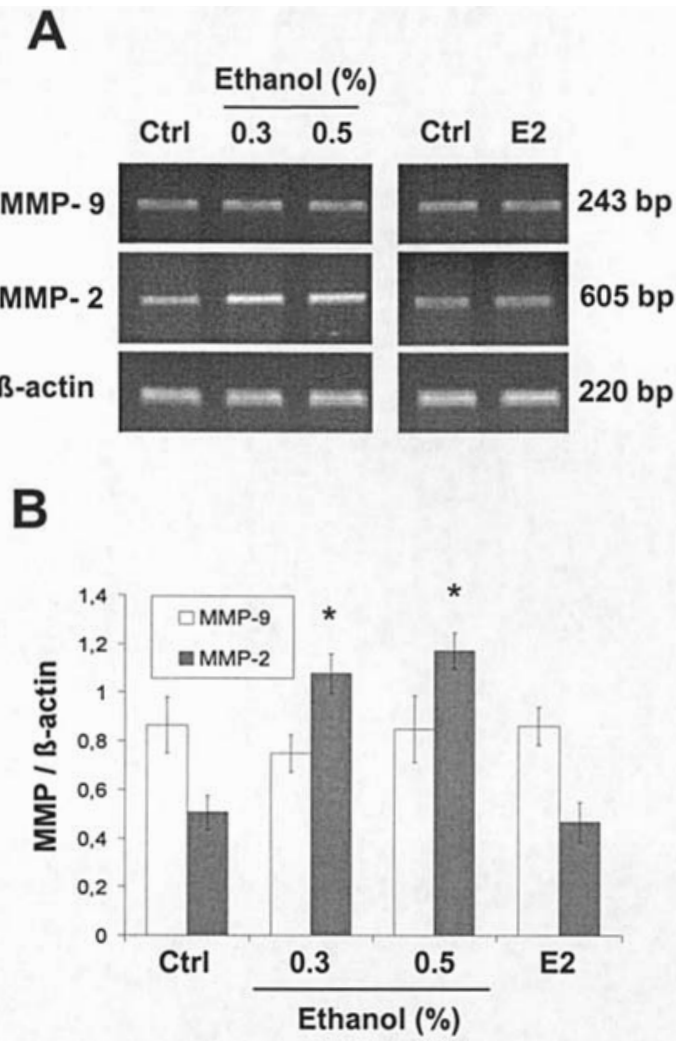

Figure 3. Ethanol stimulates MMP-2 transcription in MCF-7 human breast cancer cells. A representative gel of an RT-PCR experiment (A) shows that only MMP-2 expression is increased when MCF-7 cells are treated for $24 \mathrm{~h}$ with ethanol $(0.3$ and $0.5 \%)$. Results of the semi-quantitative analysis of 4 independent experiments are shown in the histogram (B). Error bars represent standard deviations. *Significantly different from untreated control $(\mathrm{P}<0.05)$.

\section{Discussion}

More and more epidemiological studies show that alcohol consumption is associated with an increased risk factor for breast carcinogenesis (26-28) and with advanced and invasive breast tumors $(7,8)$. These epidemiological data suggest that ethanol may enhance tumor development and the metastatic spread of breast cancer cells. This is confirmed by in vitro and in vivo studies showing that ethanol stimulates not only proliferation but also invasion and migration of breast cancer cells (9-14). Many studies have been realized in order to elucidate these effects. In MCF-7 cells, ethanol down-regulates the expression of E-cadherin and three major catenin, proteins responsible for the maintenance of cell adhesion and tissue integrity (11). In T47D human breast cancer cells, ethanol promotes metastasis by up-regulating the activity of erbB receptors (12). For our part, we have postulated that an increase in metalloproteinase expression could be involved in the stimulation of migration observed in breast cancer cells following ethanol exposure. Indeed, it has been recently shown in fibroblasts that ethanol stimulates the secretion of MMP-2 (29), which plays a critical role, together with MMP-9, in extracellular matrix degradation and tumor cell invasion in breast cancer $(15,17)$. Moreover, ethanol activates the estrogen signaling pathway in breast cancer cells $(14,21)$, and some studies show that estrogens are able to stimulate the secretion of MMP-2 and $-9(18,19)$.
By using gelatin zymography, we observed an increase in MMP-2 and -9 secretion in MCF-7 cells following ethanol exposure. For MMP-9, the maximal secretion was observed at a dose of $0.3 \%$ ethanol with a 1.6 -fold increase compared to control and, for MMP-2, the maximal secretion was observed at a concentration of $0.5 \%$ with a 1.9 -fold increase compared to control. This increase is somewhat higher than those observed when MCF-7 cells are exposed to $1 \mathrm{nM} 17 ß$-oestradiol: a 1.4-fold increase for MMP-9 secretion and a 1.8-fold increase for MMP-2. This suggests that ethanol could have a stronger metastatic potential than $\mathrm{E}_{2}$.

How does ethanol stimulate metalloproteinase secretion? An explanation for this effect could be the activation of the estrogen signaling pathway in MCF-7 cells exposed to ethanol. Indeed, several studies have shown such an effect of ethanol. For instance, following ethanol exposure, an increase occurs in the expression of aromatase, the estrogen-producing enzyme, and in the ER $\alpha$ content, the nuclear receptor mediating most of the estradiol effects $(14,30)$. Alcohol also induces a dosedependent increase in the transcription activity of the liganded estrogen receptor, ER $\alpha$ (21). Also, estradiol has been shown to stimulate MMP-2 and -9 secretions in MCF-7 cells $(18,19,31)$. The pathway by which $\mathrm{E}_{2}$ enhances MMP secretion is still unclear. It might be the result not only of nuclear estrogen receptor activation but also of the rapid stimulation of signal transduction from plasma membrane estrogen receptors that are $\mathrm{G}$ protein-coupled (31).

In order to test our hypothesis, we used an anti-estrogen; the 'pure' antagonist, ICI 182,780 (24). We determined the optimal concentration by analyzing its effect on the expression of a well-known estrogen responsive gene, the progesterone receptor (PR) (25). The concentration of $100 \mathrm{nM}$ had the best efficiency, which is in accordance with a previous study (32). We observed that this concentration could inhibit $\mathrm{E}_{2}$-induced increase in the secretion of the two MMPs. This result is in agreement with those showing that, in MCF-7 cells, another anti-estrogen, raloxifene, prevents $\mathrm{E}_{2}$-induced increase in the gelatinolytic activity of MMP-2 and -9 (19). It is also concordant with the results of another study showing that several anti-estrogens, including ICI 182,780, inhibit $\mathrm{E}_{2}$ induced MMP-9 secretion in MCF-7 cells (20). However, it is difficult to identify the nature of the estrogen receptor that mediates estradiol action on MMP-2 and -9. Indeed, ICI 182,780 is able to antagonize $\mathrm{E}_{2}$ binding not only on its nuclear receptors but also on its membrane bound receptors (31).

ICI 182,780 also prevented ethanol-induced increase in MMP-9 secretion, which could be the result of an estrogenlike action. However, ethanol stimulation was performed in serum-free medium which should contain only trace amounts of steroids. Although the level of both aromatase and ER $\alpha$ is increased in MCF-7 exposed to ethanol, it is probably insufficient to activate an estrogenic pathway in serum- and hormone-free conditions (14). One might propose that, in that case, a ligand-independent activation of ER $\alpha$ could occur. The phosphorylation of ER $\alpha$ by protein kinase A (PKA) has been well documented in this mechanism (33). Besides, forskolininduced ER activation, measured by the transcription of a reporter gene downstream a 2-ERE sequence, is inhibited by ICI 182,780 (34). Interestingly, ethanol has been shown to increase cAMP levels in MCF-7 cells (30). Hence, in our 
study, in spite of the absence of serum and steroids in the medium, ethanol exposure could induce a PKA-mediated activation of ER $\alpha$ which could activate the transcription of a gene responsible for MMP-9 secretion, explaining that this effect is inhibited by the anti-estrogen. It is noteworthy that, in the case of ligand-independent activation of ER $\alpha$, its degradation by the proteasome is inhibited in contrast to what occurs in the case of ligand-dependent activation (34). In our previous study of ethanol-treated MCF-7 cells, we observed by immunoblotting that the level of ER $\alpha$ was increased while no difference in the mRNA levels was observed by RT-PCR (14). This is in accordance with the hypothesis of a ligandindependent activation.

In contrast, ICI 182,780 had no effect on ethanol-induced MMP-2 secretion suggesting that, in this case, ethanol could use an estrogen receptor independent pathway. Interestingly, a recent study shows that, in fibroblasts, ethanol increases MMP-2 secretion by the protein kinase C pathway (PKC) (29). Nevertheless, TPA, a PKC activator, stimulated the secretion of MMP-9 while it did not change the level of MMP-2 in MCF-7 cells and in organotypic cultures of human breast cancer tissue $(35,36)$. Another explanation for ethanol-induced MMP-2 secretion might be related to free radicals. Indeed, in the hormone-independent breast cancer cells, MDA-MB-231, generation of free radicals by the estradiol metabolite, 4hydroxyestradiol, activates MMP-2 (37). So, free radicals could mediate ethanol action, especially on MMP-2. Indeed, breast cytosolic fractions can bioactivate ethanol to acetaldehyde and to hydroxyl and 1-hydroxyethyl free radicals (38).

Finally, in order to better characterize the effect of ethanol on MMP-2 and -9 in MCF-7 cells, we have performed RTPCR analyses. Our results show that $\mathrm{E}_{2}$ stimulates neither MMP-2 nor MMP-9 transcription. So, the steroid activates MMPs secretion independently of their transcription.

In the case of ethanol exposure, the level of MMP-9 mRNA did not change while those of MMP-2 mRNA increased significantly. This differential effect is not surprising since, despite the high homology in amino acid sequence between MMP-2 and -9 , their promoters are composed of different cis elements (39). Hence, they can not only respond to different stimuli but also respond differently to the same stimulus. For instance, in melanoma cells, transfection with CD9 membrane protein up-regulates the expression of MMP-2 while it downregulates MMP-9 (40). The differential regulation of MMP-2 and -9 seems also to be illustrated in MCF-7 cells in response to ethanol. The reason for the ethanol induced increase in MMP-2 transcription, as well as the relationship between MMP-2 overexpression and the stimulation of its secretion, remains unknown.

In conclusion, our study showing an increase in MMP-2 and MMP-9 secretion by MCF-7 cells in response to ethanol helps to explain the increased migration of breast cancer cells observed in response to ethanol treatment and supports data suggesting that ethanol is an increased risk factor for advanced and invasive breast tumors. Our comparison between $\mathrm{E}_{2}$ and ethanol effects shows that the two metalloproteinases are regulated differently regarding not only their secretion but also their transcription. ER $\alpha$ is clearly involved in some of the effects of ethanol but further study is required to elucidate the mechanism.

\section{Acknowledgements}

This study was supported by grants from Université Henri Poincaré (BQR), Ligue Contre le Cancer, Comité de la Meurthe et Moselle, et Comité de la Meuse, Association pour la Recherche sur le Cancer, Cancéropole Grand Est, Institut de Recherches Scientifiques sur les Boissons and Conseil Régional de Lorraine. N.E. is a recipient of a doctoral grant from the Ligue Contre le Cancer, Comité de la Meurthe et Moselle. We would like to thank Martine Callier for technical assistance in molecular biology.

\section{References}

1. Boyle P and Ferlay J: Cancer incidence and mortality in Europe, 2004. Ann Oncol 16: 481-488, 2005.

2. Weichselbaum RR, Hellman S, Piro AJ, Nove JJ and Little JB: Proliferation kinetics of a human breast cancer line in vitro following treatment with 17beta-estradiol and 1-beta-D-arabinofuranosylcytosine. Cancer Res 38: 2339-2342, 1978.

3. Reddel RR and Sutherland RL: Tamoxifen stimulation of human breast cancer cell proliferation in vitro: a possible model for tamoxifen tumour flare. Eur J Cancer Clin Oncol 20: 1419-1424, 1984

4. Lykkesfeldt AE and Briand P: Indirect mechanism of oestradiol stimulation of cell proliferation of human breast cancer cell lines. Br J Cancer 53: 29-35, 1986.

5. Pasqualini JR, Chetrite G, Blacker C, Feinstein MC, Delalonde L, Talbi M and Maloche C: Concentrations of estrone, estradiol, and estrone sulfate and evaluation of sulfatase and aromatase activities in pre- and post-menopausal breast cancer patients. J Clin Endocrinol Metab 81: 1460-1464, 1996.

6. Chen S, Itoh T, Wu K, Zhou D and Yang C: Transcriptional regulation of aromatase expression in human breast tissue. J Steroid Biochem Mol Biol 83: 93-99, 2002.

7. Vaeth PA and Satariano WA: Alcohol consumption and breast cancer stage at diagnosis. Alcohol Clin Exp Res 22: 928-934, 1998.

8. Stoll BA: Alcohol intake and late-stage promotion of breast cancer. Eur J Cancer 35: 1653-1658, 1999.

9. Przylipiak A, Rabe T, Hafner J, Pryzylipiak M and Runnebaum B: Influence of ethanol on in vitro growth of human mammary carcinoma cell line MCF-7. Gynecol Obstet 258: 137-140, 1996.

10. Singletary K: Ethanol and experimental breast cancer: a review. Alcohol Clin Exp Res 21: 334-339, 1997.

11. Meng Q, Gao B, Goldberg ID, Rosen EM and Fan S: Stimulation of cell invasion and migration by alcohol in breast cancer cells. Biochem Biophys Res Commun 273: 448-453, 2000.

12. Luo J and Miller MW: Ethanol enhances erbB-mediated migration of human breast cancer cells in culture. Breast Cancer Res Treat 63: 61-69, 2000 .

13. Izevbigie EB, Ekunwe SI, Jordan J and Howard CB: Ethanol modulates the growth of human breast cancer cells in vitro. Exp Biol Med 227: 260-265, 2002.

14. Etique N, Chardard D, Chesnel A, Merlin JL, Flament S and Grillier-Vuissoz I: Ethanol stimulates proliferation, ERalpha and aromatase expression in MCF-7 human breast cancer cells. Int J Mol Med 13: 149-155, 2004.

15. Nakajima M, Welch DR, Belloni PN and Nicolson GL: Degradation of basement membrane type IV collagen and lung subendothelial matrix by rat mammary adenocarcinoma cell clones of differing metastatic potentials. Cancer Res 47: 4869-4876, 1987.

16. Tryggvason K, Hoyhtya M and Salo T: Proteolytic degradation of extracellular matrix in tumor invasion. Biochim Biophys Acta 907: 191-217, 1987

17. Egeblad M and Werb Z: New functions for the matrix metalloproteinases in cancer progression. Nat Rev Cancer 2: 161-174, 2002.

18. Mitropoulou TN, Tzanakakis GN, Kletsas D, Kalofonos HP and Karamanos NK: Letrozole as a potent inhibitor of cell proliferation and expression of metalloproteinases (MMP-2 and MMP-9) by human epithelial breast cancer cells. Int J Cancer 104: 155-160, 2003. 
19. Wolczynski S, Surazynski A, Swiatecka J and Palka J: Estrogenic and antiestrogenic effects of raloxifene on collagen metabolism in breast cancer MCF-7 cells. Gynecol Endocrinol 15: 225-233, 2001.

20. Abbas Abidi SM, Howard EW, Dmytryk JJ and Pento JT: Differential influence of antiestrogens on the in vitro release of gelatinases (type IV collagenases) by invasive and non-invasive breast cancer cells. Clin Exp Metastasis 15: 432-439, 1997.

21. Fan S, Meng Q, Gao B, Grossman J, Yadegari M, Goldberg ID and Rosen EM: Alcohol stimulates estrogen receptor signaling in human breast cancer cell lines. Cancer Res 60: 5635-5639, 2000.

22. Fazzari A, Catalano MG, Comba A, Becchis M, Raineri M, Frairia R and Fortunati N: The control of progesterone receptor expression in MCF-7 breast cancer cells: effects of estradiol and sex hormone-binding globulin (SHBG). Mol Cell Endocrinol 172: 31-36, 2001.

23. Bartsch JE, Staren ED and Appert HE: Matrix metalloproteinase expression in breast cancer. J Surg Res 110: 383-392, 2003.

24. Wakeling AE and Bowler J: ICI 182,780, a new antioestrogen with clinical potential. J Steroid Biochem Mol Biol 43: 173-177, 1992.

25. Vegeto E, Cocciolo MG, Raspagliesi F, Piffanelli A, Fontanelli R and Maggi A: Regulation of progesterone receptor gene expression. Cancer Res 50: 5291-5295, 1990.

26. Aronson K: Alcohol: a recently identified risk factor for breast cancer. Can Med Assoc J 168: 1147-1148, 2003.

27. Longnecker MP: Alcoholic beverage consumption in relation to risk of breast cancer: meta-analysis and review. Cancer Causes Control 5: 73-82, 1994.

28. Wolff MS and Weston A: Breast cancer risk and environmental exposures. Environ Health Perspect 105: 891-896, 1997.

29. Aye MM, Ma C, Lin H, Bower KA, Wiggins RC and Luo J: Ethanol-induced in vitro invasion of breast cancer cells: the contribution of MMP-2 by fibroblasts. Int J Cancer 112: 738-746, 2004.

30. Singletary KW, Frey RS and Yan W: Effect of ethanol on proliferation and estrogen receptor-alpha expression in human breast cancer cells. Cancer Lett 165: 131-137, 2001.

31. Razandi M, Pedram A, Park ST and Levin ER: Proximal events in signaling by plasma membrane estrogen receptors. J Biol Chem 278: 2701-2712, 2003.
32. De Cremoux P, Tran-Perennou C, Brockdorff BL, Boudou E, Brunner N, Magdelenat $\mathrm{H}$ and Lykkesfeldt AE: Validation of real-time RT-PCR for analysis of human breast cancer cell lines resistant or sensitive to treatment with antiestrogens. Endocr Relat Cancer10: 409-418, 2003.

33. Cenni B and Picard D: Ligand-independent activation of steroid receptors: new roles for old players. Trends Endocrinol Metab 10: 41-46, 1999.

34. Tsai HW, Katzenellenbogen JA, Katzenellenbogen BS and Shupnik MA: Protein kinase A activation of estrogen receptor alpha transcription does not require proteasome activity and protects the receptor from ligand-mediated degradation. Endocrinology 145: 2730-2738, 2004.

35. Liu JF, Crepin M, Liu JM, Barritault D and Ledoux D: FGF-2 and TPA induce matrix metalloproteinase-9 secretion in MCF-7 cells through PKC activation of the Ras/ERK pathway. Biochem Biophys Res Commun 293: 1174-1182, 2002.

36. Wu TT, Tsai JH, Tsai JH, Kuo SJ, Yu SY, Huang CY, Hsieh HY, Hsieh YS and Liu JY: Augmented release of matrix metalloproteinase- 9 by PKC activation in organotypic cultures of human breast cancer and adjacent normal breast tissue and fibroadenoma. Chin J Physiol 47: 73-78, 2004.

37. Paquette B, Bisson M, Baptiste C, Therriault H, Lemay R and Cantin AM: Invasiveness of breast cancer cells MDA-MB-231 through extracellular matrix is increased by the estradiol metabolite 4-hydroxyestradiol. Int J Cancer 113: 706-711, 2005.

38. Castro GD, Delgado de Layno AM, Costantini MH and Castro JA: Cytosolic xanthine oxidoreductase mediated bioactivation of ethanol to acetaldehyde and free radicals in rat breast tissue. Its potential role in alcohol-promoted mammary cancer. Toxicology 160: 11-18, 2001.

39. Westermarck J and Kahari VM: Regulation of matrix metalloproteinase expression in tumor invasion. FASEB J 13: 781-792, 1999.

40. Hong IK, Kim YM, Jeoung DI, Kim KC and Lee H: Tetraspanin CD9 induces MMP-2 expression by activating p38 MAPK, JNK and c-Jun pathways in human melanoma cells. Exp Mol Med 37: 230-239, 2005. 